\title{
Mental Health and Subjective Well-Being among Blue - Collar and White - Collar Employees: A Study With Reference To Textile Industries of Northern India
}

\author{
Dr. Ajay Kumar ${ }^{*}$, Prof. Anis Ahmad ${ }^{2}$ \\ ${ }^{1}$ Associate Professor \& Head, Department of Psychology, Jagjiwan College (a constituent unit of Veer Kunwar Singh University, Ara), Ara - 802312 \\ India \\ ${ }^{2}$ University Department of Psychology, L.N. Mithila University Darbhanga - 846004
}

DOI: $\underline{10.36348 / \text { sjhss.2019.v04i12.002 }}$

| Received: 10.12.2019 | Accepted: 17.12.2019 | Published: 20.12.2019

*Corresponding author: Dr. Ajay Kumar

\section{Abstract}

The present study was aimed at studying the levels of mental health and subjective well- being among blue collar and white collar employees working in different textiles industries of Northern India. For the present study, total sample consisted of one hundred fifty employees $(\mathrm{N}=150)$ comprising blue collar $(\mathrm{n}=90)$ and white collar $(\mathrm{n}=60)$ employees were randomly drawn from Mau - a well-known district of Uttar Pradesh where Silk Sarees and different kinds of textile materials are manufactured and being marketed though out the nation. The age ranges of employees are recorded between 22 and 55. The various dimensions of mental health like positive self-evaluation, realistic perception, integration of personality, autonomy, group - oriented attitude and environmental mastery were measured using Mental Health Inventory. PGI Well Being Scale was used to assess the subjective - well- being. Findings of the study revealed that generally the levels of various dimensions of mental - health - well- being were better among blue collar employees of textiles industries than white collar employees especially from where the present sample has been drawn, although, both the group of employees of textile industries have shown positive inclination towards subjective well-being. Moreover, such type of results obtained has been discussed in detail by highlighting the appropriate probable reasons.

Keywords: Mental Health, Subjective Well - Being, Blue - Collar, White - Collar, Employees, Textile, Industries, Northern, India.

Copyright @ 2019: This is an open-access article distributed under the terms of the Creative Commons Attribution license which permits unrestricted use, distribution, and reproduction in any medium for non-commercial use (NonCommercial, or CC-BY-NC) provided the original author and source are credited.

\section{INTRODUCTION}

In this modern industrialized era health is an essential aspect of human life. It is well-recognized truth from the time immemorial that possessing good health is pre-requisite for every human being for allround growth and development. The sole objective of health is to make the individual and the community health conscious. In this context, Mahatma Gandhi father of Indian Nation viewed that "We must first know enough of our body, our own house, our village and its surroundings, the crops that grow there and its history before going on to anything else. It is also important to mention here that Word Health Organization [1] suggested certain aims of health education. They are:

- To ensure that health is valued as an asset in the community.
- To equip the people with skills, knowledge and attitudes to enable them solve their health problems by their own actions and efforts.

- To promote the development and proper use of health services.

- To create good human relations.

- Cultivating reinforcement, motivation of known to unknown etc.

The word "Mental" means "of the mind". It describes our thoughts, feelings and understanding of ourselves and the world around us. The word "health" generally describes the working order of our body and mind. So, that when we talk about mental health we refer it to the working order of an individual's mind.

Mental health, however, is a contested and still much debated concept, with no universally accepted definition [2,3]. In fact, it has been argued that there can be no universally accepted definition $[2,3]$ due to the 
fact that mental health is multi-dimensional and valueladen. A wide range of meanings and definitions exist amongst individuals, reflecting, for example, differences in terms of age, sex, socio-cultural contexts, experiences, and lack of common language. Additionally, interpretations are dynamic and mental health is often used interchangeably with, emotional, psychological and subjective well-being. Thus, no definition is ideal or without problems and mental health is more complex and subjective than any definition in this regard. It is recognized that focusing on achieving a consensus on definitions of an abstract concept like mental health may not be the most beneficial use of efforts or necessary [2-4]. However, the way mental health is defined and conceptualized will affect how it is measured.

Mental health is defined as a state of wellbeing in which every individual realizes his or her own potential, can cope with the normal stresses of life, can work productively and fruitfully and is able to make a contribution to her or his community. The World Health Organization defines mental health as "a state of wellbeing in which the individual realizes his or her own abilities, can cope with the normal stresses of life, can work productively and fruitfully and is able to make a contribution to his or her community [5]". According to Menninger [6], it is the ability of human being to adjust to the world and to each other with maximum effectiveness and happiness. Boehm [7] says that the condition and level of mental health should be socially acceptable. According to Charandas [8] mental health is the adjustment of human being to the world and to each other with maximum of effectiveness and happiness. It is an important aspect of one's total health. From perspectives of the discipline of positive psychology mental health may include an individual's ability to enjoy life and procure a balance between life activities and efforts to achieve psychological resilience [9].

One of the bona fide scholars, viz., Weare [10] is of the personal opinion that mental health is getting its deeper concern with some important positive characteristics of the individual such as: resilience and an inner sense of coherence; the ability to make relationships, to attach to others and to love the ability to think clearly including emotional matters; the ability to manage the emotions successfully and appropriately; the ability to be sensitive to one's own and other's emotions; and the capacity to have an accurate selfconcept and high self-esteem[11,12,13.

In the recent past the field of Global Mental Health has emerged, and defined as 'the area of study, research and practice that places a priority on improving mental health and achieving equity in mental health for all people worldwide[14'.

The term mental health has been classified into two different broader categories known as positive and negative mental health. Mental heath from the positive angle refers to behavior, attitudes and feeling that respect an individual's level of personal effectiveness, success and satisfaction. Argyris [51] suggested that persons with positive mental health should have the ability to understand the realities which exists both externally and internally when he/she strives to be aware of their oneself. Buck [16] found that employees who reported working under pressure indicated decreased mental health. Emmons [17] viewed that mentally healthy persons are able to fulfill their social roles successfully. They enjoy peace of mind, happiness, self confidence and others' companionship. Negative mental health covers a wide variety of deep feelings including sorrow, disappointment, anger and empathy etc. O'Neil and others [18] found that stress in the work environment has a negative impact on the physical and mental health of working women. Rastogi and Kavita [19] found a significant negative relationship between occupational stress and mental health. Nagaratnamma [20] says that employees of different organizations differ with regards to their mental health. According to Johns et al. [21] mental health is a condition which is characteristics of the average person who meets the demands of life on the basis of his own capacities and limitations. In addition to it Hadfield [22] viewed that mental health is the full and harmonious functioning of the whole personality. It is therefore, a positive and active quality of the individual's daily living. In one of the important studies Mahendran [23] found that there was no significant difference between male and female teacher trainees on mental health.

Mental health impairments popularly known as mental illness refer to all diagnosable mental disorders. Mental disorders are health conditions that are characterized by alterations in thinking, mood or behavior (or some combinations thereof) associated with distress and/or impaired functioning [24]. Some common mental health impairments are: depression, bipolar disorder, schizophrenia, PTSD, OCD, panic disorder and seasonal affective disorder etc.

An analysis of fifteen major studies conducted over last forty years on the prevalence of mental disorders in India by Ganguli [25] suggested that 73 persons have mental disorders in a population of 1000 persons. Sharma and Singh [26] revealed that in the state of Goa the prevalence of mental disorder was $60 \%$, more among males as compare to females and likewise it was found much higher among Christians as compared to Hindus; but it was found very much similar in urban and rural areas.

Mental health is the launch pad of thinking, communication skills, learning, emotional growth, and resilience and self-steam. It is how people look at themselves, their lives and the other people in their lives; evaluate their challenges and problems; and 
explores choices. This includes handling stress, relating to other people and making decisions. Sanadnarj et al. [27] investigates the relationship between physical health and mental health among 260 male and 252 females' higher secondary school students in Tamil Nadu. They studied 10 physical health variables and 6 mental health variables. Among the 60 correlations computed between physical health and mental health variables, 57 correlations were significant at 0.01 level and the remaining three were significant at the 0.05 level. It was found that those who enjoy good physical health are most likely to have better mental health as compare to those who are suffering from poor mental health.

A meta-analytic review by Stansfeld and Candy [28] provides robust consistent evidence that (combination of) high demands and low decision latitude and (combination of) high efforts and low rewards are prospective risk factors for common mental disorders and suggested that the psychological work environment is important for mental health. The impact of work stressors on common mental disorders differ from men to women.

Recently, Zilli and Ali [29] have conducted a study on mental health among players and non-players. The findings of the study revealed significant difference between players and non-players on mental health dimensions. Similarly, Zilli et al. [29] concluded that female youth scored higher on mental health dimensions as compared to their male counterparts.

However, mental health has been studied variously by scholars from different cultures of life. The preponderance of positive affect over negative affect [31], subjective well-being as a person's evaluative reaction to his or her life either in terms of life satisfaction, cognitive evaluation or affect over negative effect on ging emotional reaction [32]. There is extensive evidence of correlations between subjective well-being and general health [33]. Arrindell, Heesink and Feij [4] found that the use of medical services correlated negatively with subjective well-being. This finding was further supported by Eid and Diener [11] who showed that subjective well-being was a significant predictor of mental health levels. Some scholars argued that subjective wellbeing is not synonymous with mental health or psychological health. A delusional person might be happy and satisfied with his life, and yet we would not say that he possesses mental health. A person who is out of touch with his/her own motives and emotions might say he/she is happy, but not possess complete psychological health. Thus, subjective well-being is not a sufficient condition for psychological well-being [34, 35].

\section{Objective of the Study}

Having reviewed the extensive survey of literature on the phenomenon, it has been observed that none of the studies are available on the problem entitled "mental health and subjective well-being among blue collar and white - collar emploees: a study with reference to textiles industries of northern india; hence, the present study is of utmost value which will fill the void of knowledge in the area concerned. As it is generally assumed that Blue-collar and White - collar employees differ to each other in respect of their organizational values, other related opportunities and problems, therefore, the present investigation was planned to study mental health and subjective wellbeing between blue-collar and white collar employees with special reference to textiles industries of Northern India.

\section{Hypotheses}

In the light of the broad objectives of the present study, the following hypotheses were formulated:

1. White - Collar employees of textile industries would have better mental health as compare to Blue - Collar Employees on over all mental health inventory

2. White - collar employees would have better mental health as compare to blue - collar employees on positive self-evaluation, a dimension of mental health.

3. White - collar employees would have better mental health as compare to blue - collar employees on perception of reality - a dimension of mental health.

4. White - collar employees would have better mental health as compare to blue - collar employees on integration of personality dimension of mental health.

5. White - collar employees would have better mental health as compare to blue - collar on autonomy, a dimension of mental health.

6. White - collar employees would have better mental health as compare to blue - collar employees on group-oriented attitude, a dimension of mental health.

7. White - collar employees would have better mental health as compare to blue - collar employees on environmental mastery, a dimension of mental health.

8. There would not be significant difference between Blue - Collar and White- Collar Employees of textile industries of Northern India on their degree of subjective well-being.

\section{METHODOLOGY \\ Sample}

Total sample of the present investigation consisted of $(\mathrm{N}=150)$ textiles industries employees, comprising Blue - Collar $(n=90)$ and White - Collar $(n=60)$ employees which were randomly selected from different Textiles Industries of Mau district - a wellknown town of Textiles manufacturing companies of Northern India. Further the sample was limited to working blue - collar and white - collar employees of 
textiles industries and their age ranged between $22-55$ years.

\section{Tools used}

The following measures were used in the present piece of research work.

1. Mental Health Inventory: For measuring mental health of the employees of textiles industries a standardized mental health inventory developed by Jagdish and Srivastava [36] was used. This scale consisted of 55 items and each item was rated on 4 point rating scale ranging from always to never with a score of 1 to 4 . Inventory comprises of six dimensions such as, Positive self-evaluation (PSE), Perception of reality (PR), Integration of personality (IP), Autonomy (Autonomy), Grouporiented attitudes (GOA), and Environmental Mastery (EM). In this inventory high score indicates good mental health and low score indicates poor mental health. The reliability of the whole scale reported by author is 0.73 .

2. Subjective Well-Being Scale: For measuring employees' subjective well-being, a scale developed by Verma, et al. [37] was used. It is a 20 item scale, which measures the subjective wellbeing. The scoring of the scale is very simple. The more number of 'yes' indicates higher level of subjective well-being. The reliability of the scale is 0.86 .

3. Biographical Information Blank (BIB): Biographical Information Blank (BIB) was also prepared and used for analyzing the obtained results. Information included in it was like age, income, job tenure, number of depends, total working experience, qualifications, etc.

\section{Procedure}

These two materials were in printed form and were administered on each employee of textiles industries who were engaged in manufacturing the high quality of Sarees and other materials of textiles industries processes either in private or government located in Mau city and around Mau district by giving assurance that information provided by them will be kept strictly confidential.

The responses were scored according to the procedure and the individual scores were obtained. Having obtained the data, the data were tabulated for giving statistical treatment for obtaining the results and presented in tables. Finally, the results were discussed and the formulated hypotheses were tested.

\section{RESULTS AND DISCUSSION}

In quest of investigation the degree mental health and subjective well-being among the blue - collar and white - collar employees of textile industries, Table-1 clearly indicates that in the case of blue - collar employees the mean and SD was found to be 128.42 and 8.12, while in the case of white - collar employees the Mean and SD was found to be 119.83 and 6.72 respectively as ' $t$ ' has been found 6.05 which is statistically highly significant at 0.01 level of confidence. Thus, proves the present underlying major hypothesis of our present piece of research that "white collar employees of textiles industries especially in Mau district from where the present sample has been drawn would have better mental health as compare to blue collar employees on overall mental health dimensions" stand rejected. It is important to be mentioned that especially in Mau district blue - collar employees have been recorded higher degree of mental health than white - collar employees, hence, significance of difference on different dimensions of mental health have also been found between the group of blue - collar and white collar employees. Table -1 also indicates that four dimensions of mental health out of six namely, "Positive Self-Evaluation", "Realistic Perception", "Autonomy" and "Group-Oriented Attitude" have been found as the predictors of mental health between the group of blue - collar employees and white - collar employees in the textiles industries of Mau district - a well-known textiles manufacturing district of Northern India as their " $\mathrm{t}$ " values $8.64,6.5,10.58,3.29$ respectively have been found statistically highly significant at 0.01 level of confidence.

Table - 1: Showing Mean, SD and $t$ - values between the group of Blue - Collar and White- Collar of Employees working in Textiles Industries of Northern India on different dimensions of Mental Health and in Total Mental Health of all Employees.

\begin{tabular}{|c|c|c|c|c|c|}
\hline Dimensions of Mental Health & Group & $\mathbf{N}$ & Mean & SD & 't' values \\
\hline \multirow[t]{2}{*}{ Positive Self-Evaluation } & Blue - Collar & 90 & 36.12 & 3.72 & \multirow[b]{2}{*}{$8.64^{*}$} \\
\hline & White - Collar & 60 & 29.81 & 4.76 & \\
\hline \multirow[t]{2}{*}{ Realistic Perception } & Blue - Collar & 90 & 20.65 & 1.67 & \multirow[t]{2}{*}{$6.5^{*}$} \\
\hline & White - Collar & 60 & 22.08 & 0.56 & \\
\hline \multirow{2}{*}{ Integration of Personality } & Blue - Collar & 90 & 15.25 & 1.68 & \multirow{2}{*}{$1.33^{\mathrm{NS}}$} \\
\hline & White - Collar & 60 & 14.89 & 1.52 & \\
\hline \multirow[t]{2}{*}{ Autonomy } & Blue - Collar & 90 & 20.72 & 1.12 & \multirow[b]{2}{*}{$10.58^{*}$} \\
\hline & White - Collar & 60 & 18.17 & 1.62 & \\
\hline \multirow[t]{2}{*}{ Group - Oriented Attitude } & Blue - Collar & 90 & 16.82 & 1.23 & \multirow[b]{2}{*}{$3.29 *$} \\
\hline & White - Collar & 60 & 16.17 & 1.14 & \\
\hline \multirow[t]{2}{*}{ Environmental Mastery } & Blue - Collar & 90 & 18.86 & 1.53 & \multirow[b]{2}{*}{$0.79^{\mathrm{NS}}$} \\
\hline & White - Collar & 60 & 18.71 & 0.71 & \\
\hline \multirow[t]{2}{*}{ Total Mental Health } & Blue - Collar & 90 & 128.42 & 8.12 & \multirow[t]{2}{*}{$6.05 *$} \\
\hline & White - Collar & 60 & 119.83 & 6.72 & \\
\hline
\end{tabular}


Table- 2 is the extension of table -1 which clearly revealed the fact that $42.22 \%$ of blue - collar employees of textiles industries have shown higher level of acceptance to their mental health in comparison to their white - collar employee i.e. $45 \%$ which is comparatively higher than blue - collar employees.
$46.67 \%$ of blue - collar employees have shown moderate level of acceptability than white - collar employees $(43.33 \%)$, although, $11.67 \%$ of white collar employees have indicated little higher degree on low levels than blue - collar employees i.e. $11.11 \%$.

Table-2: Showing the Comparative Difference between blue - collar and white collar employees of textiles industries on their levels of Mental Health

\begin{tabular}{|c|c|c|c|c|}
\hline \multirow{2}{*}{ Levels } & \multicolumn{2}{|c|}{$\begin{array}{c}\text { Blue - Collar Employees } \\
(\mathbf{N = 9 0 )}\end{array}$} & \multicolumn{2}{c|}{$\begin{array}{c}\text { White - Collar Employees } \\
\text { (N=75) }\end{array}$} \\
\cline { 2 - 5 } & $\mathrm{n}$ & Percentage & $\mathrm{n}$ & Percentage \\
\hline High & 38 & $42.22 \%$ & 27 & $45 \%$ \\
\hline Moderate & 42 & $46.67 \%$ & 26 & $43.33 \%$ \\
\hline Low & 10 & $11.11 \%$ & 07 & $11.67 \%$ \\
\hline
\end{tabular}

Above mentioned results pertaining to the comparative difference between blue - collar and white - collar employees of textile industries on their levels of perceived reactions on mental health can also be observed by the following diagram:

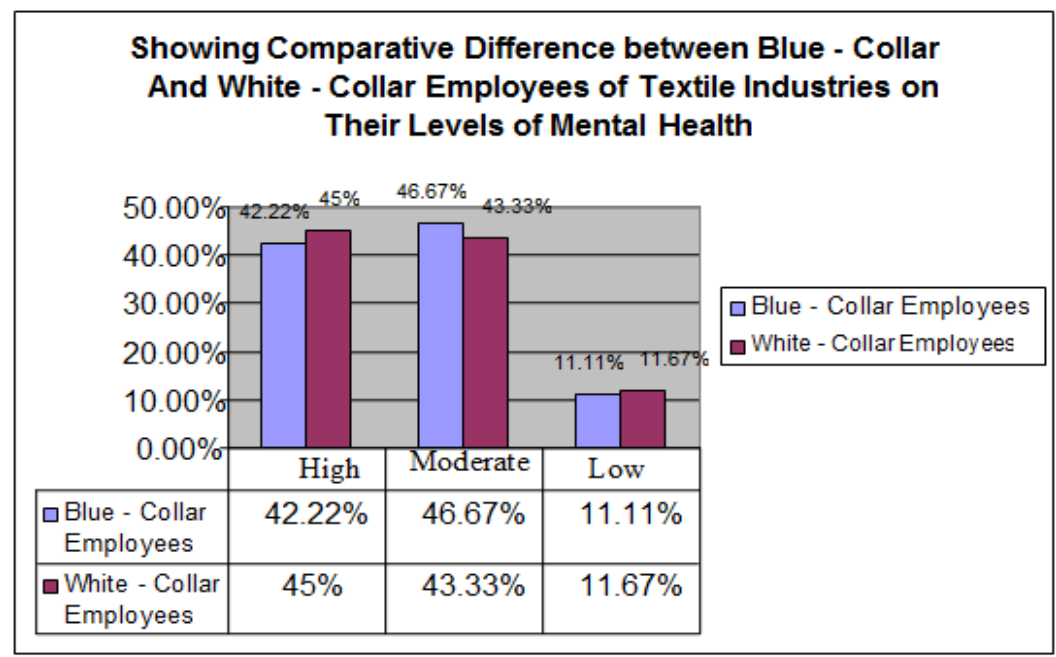

Table -3 of the results depict the picture regarding significance of difference on Subjective Wellbeing between the group of Blue - Collar and White Collar employees of Textiles industries of Mau district - a well-known textile manufacturing district of Northern India. Table revealed the fact that white - collar employees scored higher degree on the scale of subjective well-being than their blue- collar employees, hence, ' $t$ ' $=17.05$ has been found highly significant at 0.01 level of confidence. Thus, the proposed hypothesis i.e. there will be no significant difference between the groups on subjective well-being stands rejected.

Table-3: Showing significance of difference on Subjective Well -Being between the group of Blue - Collar and White - collar Employees working in Textiles Industries of Northern India.

\begin{tabular}{|c|c|c|c|c|c|}
\hline VARIABLE & GROUP & N & MEAN & SD & 't' \\
\hline Subjective & Blue - Collar & 90 & 12.87 & 1.11 & \multirow{2}{*}{$17.05^{*}$} \\
\cline { 2 - 5 } Well-Being & White - Collar & 60 & 16.28 & 1.26 & \multirow{2}{*}{ W } \\
\hline
\end{tabular}

Table -4 is also extension of table -3 which reveals the comparative difference between blue collar and white - collar employees of textiles industries on the levels of subjective well-being. From the table -4 , it can be observed that $48 \%$ of white collar employees of textiles industries have shown higher degree of subjective well - being than blue collar employees i.e. $46.67 \%$ which is comparative low, although, $40 \%$ of blue - collar employees have inclined moderate level of subjective well-being than white collar employees i.e. $36.67 \%$ which is comparatively low. From the table-4, it can also be observed that $13.33 \%$ of blue - collar employees have shown their low level acceptability towards subjective well- being in comparison to their white - collar group i.e. $15 \%$ which is comparatively. 
Table-4: Showing the Comparative Difference between blue - collar and white collar employees of textiles industries on their levels of Subjective Well - Being

\begin{tabular}{|c|c|c|c|c|}
\hline \multirow{2}{*}{ Levels } & \multicolumn{2}{|c|}{$\begin{array}{c}\text { Blue - Collar Employees } \\
(\mathbf{N = 9 0 )}\end{array}$} & \multicolumn{2}{c|}{$\begin{array}{c}\text { White - Collar Employees } \\
\text { (N=60) }\end{array}$} \\
\cline { 2 - 5 } & $\mathrm{n}$ & Percentage & $\mathrm{n}$ & Percentage \\
\hline High & 42 & $46.67 \%$ & 29 & $48.33 \%$ \\
\hline Moderate & 36 & $40 \%$ & 22 & $36.67 \%$ \\
\hline Low & 12 & $13.33 \%$ & 09 & $15 \%$ \\
\hline
\end{tabular}

Above mentioned obtained results pertaining to comparative difference between blue - collar and white - collar employees working in textile industries of Mau can also be observed by the following line chart given below:

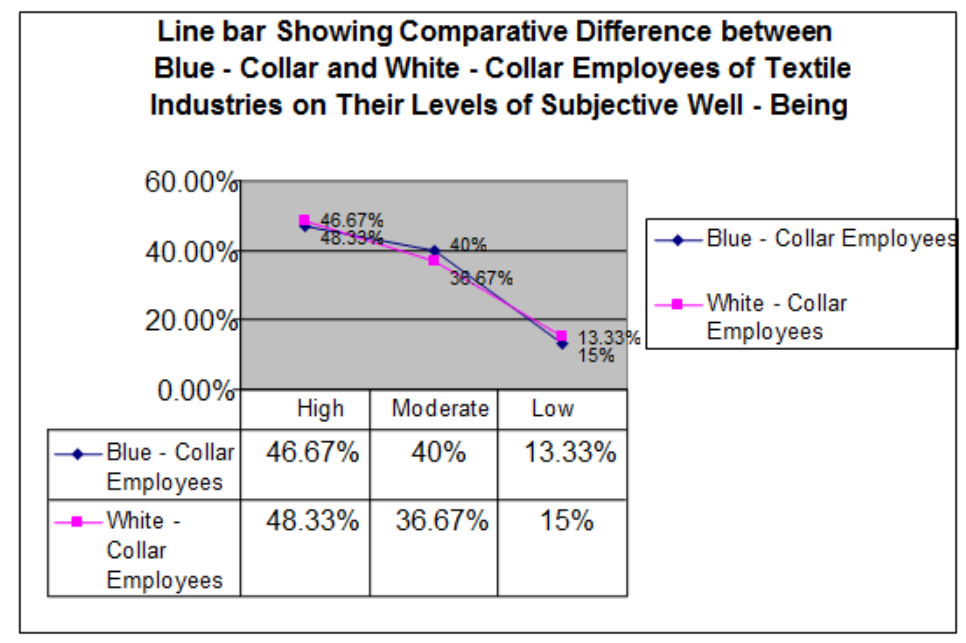

Aforementioned results can also be summarized that blue - collar employees are relatively more prone to higher degree of mental health than white - collar employees, although both the group of employees have been found favorable inclination to mental health as well as subjective well-being. But it is interesting to point out that significance of difference have also been found between blue-collar and whitecollar employees in the extent of mental health as well as in the extent of perceived reactions to subjective well-being.

Discussing the results obtained it is pertinent to mention the reason for such obtained results lie in the fact of working system of textiles industries of northern India especially in Mau district where every employee, irrespective of age, caste and religion is engaged in working in textile manufacturing companies where they have their prime objective to serve the organization and to bring money for enhancing and catering the needs of the family. Therefore, the results, as presented in table: $1-4$, seem to be logical for both the group of employees as it is often seen in our social system that the primary responsibility of the male members of the family is to earn bred for its members by taking some job. Hence, blue - collar employees also seem to have started sharing this responsibility in comparison to white - collar employees so, both the group of employees indicated relatively higher degree of mental health as well as in their perceived reactions to subjective well-being.

While concluding the discussion, it is necessary to stress light on the aforementioned reasons as experienced by present investigator. The district Mau - a well-known industrial town of Northern India where handloom and power-loom products are making rapid head way in manufacturing different verities of saree products and other textiles materials e.g. Lungies, Cashmillon cloths, Zari Cloths and materials and Cotton cloths, etc. The district Mau is being recognized as the largest producers of high quality of sarees. Thus the general reputations attached to textile manufacturing especially to saree manufacturing companies of Mau which help to develop among its employees psychological feeling of worthiness and importance and these job incumbents feel pleasure in taking up challenges while working in textiles industries especially in saree manufacturing companies of Mau, hence, the positive attitude has been found in relation to mental health as well as subjective well - being but significance of difference of difference has also been found between the group of blue - collar and white collar employees on the variables which shows only the dignity of employees in terms of position, power and social status which are important for any organization to maintain its overall efficiency as Jahoda [38] has said that aspects of attitudes toward self, growth and development, self - actualization, integration of 
personality and mastery of environment must be considered in judging whether a person is mentally healthy or not.

\section{CONCLUSIONS}

In the pretext of the results obtained and its interpretations the conclusions drawn may be summed up as follows:

1. Blue - collar and white - collar employees of textile industries of Mau district - a well-known textiles industrial town of Northern India have indicated favorable inclination to their degree of mental health, although significance of difference have been found on over all dimensions mental health.

2. Significance of difference have been found between the blue - collar and white - collar employees on different dimensions of mental health as 'Positive Self - Evaluation', Realistic Perception', Autonomy' and 'Group - Oriented Attitude' have been emerged as the predictors of mental health.

3. White - Collar employees of textiles industries of Mau district have shown higher of subjective wellbeing than Blue -Collar employees, although, Blue - Collar employees had shown higher degree of inclination towards mental health.

4. In highlighting the textiles industries especially saree manufacturing companies of Mau - a wellknown industrial township of Northern India some of the observations experienced by the present investigator, have revealed the fact that saree weaving community and those who attached with saree manufacturing companies in Mau district has unique work culture where each and every employees either white - collar or blue- collar, even an owner of the company of textiles manufacturing industries work as an ordinary employee without having any feeling of shyness, inferiority and sense of losing esteem needs, thus, everyone in that socio - cultural milieu have positively high work ethics and greater sense of commitment with whom they have their professional affiliation. Thus, both the group of employees have shown positive attitude so far as mental health and subjective well - being are concerned.

\section{REFERENCES}

1. World Health Organizatio. (1950). (The Magazine of World Health Organization), Cited in BHAVE., V. N. (1983). You and Your Health. New Delhi: National Book Trust.

2. Herron, S., \& Trent D.R. (2000). Mental health: A secondary concept to mental health illness. International Journal of Mental Health Promotion, 2, 29-38.

3. Friedli, L. (2004). Mental health improvement 'concepts and definitions': Briefing paper for the
National Advisory Group.. Edinburgh, Scottish Executive.

4. Arrindeell, W. A., Heesink, J. \& Feij, J.A. (1999). The satisfaction with life scale (swls) : appraisal with 1700 healthy young adults in Netherlands. Personality \& Individual Differences, 26, 815 826.

5. World Health Organization. (2005). Promoting Mental Health: Concepts, Emerging evidence, Practice: A report of the World Health Organization, Department of Mental Health and Substance Abuse in collaboration with the Victorian Health Promotion Foundation and the University of Melbourne. World Health Organization. Geneva.

6. Menninger, K. A. (1945). The human mind.

7. Boehm, W.W. (1995). The role of psychiatric social work in mental health. In A.M. Rose (Ed.), Mental Health and Mental Disorder. New York: Norton.

8. Charandas, N. (1986). Mental health and the community. Indian Journal of Community Guidance and Service, 3(2), 25-27.

9. About.com. (2006). What is Mental Health? Retrieved June 1, 2007, from About.com

10. Weare, K. (2004). Developing the Emotionally Literate School. London: Sage.

11. Eid, M. \& Diener, E. (1999). Intra-individual variability in affect: reliability, validity, and personal correlates. Journal of Personality \& Social Psychology, 51, 1058-1068.

12. Health Education Authority. (1997). Mental Health Promotion: A quality framework. London: HEA.

13. World Health Organization. (2004). Promoting mental health: Concepts, emerging evidence, practice (Summary report). Geneva: Author.

14. Patel, V., \& Prince, M. (2010). Global mental health - a new global health field comes of age. JAMA, 303, 1976-1977.

15. Argyris, C. (1951). Integration of the Individual and organization, New York: John Wiley.

16. Buck, V.E. (1972). Working under pressure. London: Staples Press.

17. Emmon, R.A. (1992). Abstract vs. Concrete goals: Personal striving level, physical illness and psychological well-being. Journal of Personality and Social Psychology, 62, 292-300.

18. O'Neil, Collen, P., \& Neichner, A. (1985). Working women: A Study of relationship between stress coping and health. Journal of Psycosomatic Obstetrics and Gynecology, 4(2), 105-116.

19. Rastogi, R., \& Kavita K. (2001). A study of occupational stress and mental health among married working women. Journal of Community Guidance and Research, 18(2), 189-196.

20. Nagaratnamma, B. (1999). Organizational employees and their mental health status, Journal of Community Guidance and Research, 16(2), 101109. 
21. Johns, E.B., Sutton, W. \& Webster, L.E. (1989). Health of Effective Living, New York: McGraw Hill Book Co.

22. Hadfield, J. A. (1988). The relationship between attitudes and physical impairments among deaf students, Dissertation and Abstract International, 50: 1625 - 1626 .

23. Mahendran, P. (2010). An investigation of Mental Health Status of the Diet Teacher Trainees. Journal of Community Guidance and Research. Vol. 27, No. No. 3. Pp. 405 - 414.

24. MacDonald, G. (1999). Problems, possibilities, people power and passion: What mental health promotion is and what it is not: a response to the inaugural issue. International Journal of Mental Health Promotion, 1, 37-43.

25. Ganguli, H.C. (2000). Epidemiological findings on prevalence of mental disorders in India. Indian Journal of Psychiatry, 4(21): 14-20.

26. Sharma, S., \& Singh, M.M. (2001). Prevalence of mental disorders: An epidemiological study in Goa. Indian Journal of Psychiatry, 43(2).

27. Sam Sanandaraj, H., Mohanan, A., \& Mukundan, R. (1988). Certain variables of physical and mental health: A correlational analysis. Journal of Psychological research, 42, 122-129.

28. Stansfeld, S., \& Candy, B. (2006). Psychological work environment and mental health- a metaanalytical review. Scand J Work Environ Health, 32 (6, special issue), 443-462.
29. Zilli A.S., Ali. A. (2009). Mental health among players and non-players. Indian Journal of Human Relations, 35, 8-13.

30. Zilli, A.S., Zeenat, Z., Charli. (2009). Mental health among Male and Female Youths, paper presented at a National Conference on Revamping Mental Health Programmes, T. D. College, Jaunpur, February, 23-24.

31. Bradburn, N. M. (1969). The structure of psychological well-being.

32. Diener, E., \& Diener, M. (1995). Cross-cultural correlates of positive mental health, New York: Mc Graw Hill.

33. Diener, E. (2000). Subjective Well - Being: The Science of Happiness and a proposal for a national index. American Psychologist, 55, 34-43.

34. Ryff, C.D. (1989). Happiness is everything, or is it? Explorations on the meaning of psychological wellbeing. Journal of Personality and Social Psychology, 57, 1069-1081.

35. Ryff, C. D., \& Keyes, C. L. (1995). The structure of Psychological Well- Being revisited. Journal of personality and Social psychology, 69, 719-727.

36. Jagdish., \& Srivastava, A. K. (2003). Mental Health Inventory, Varanasi: Manovaigyanik Parkahhan Sansthan.

37. Verma, S.K., Dubey, B. L., \& Gupta, D. (1983). PGI General Well-Being Scale: Some Correlates. Indian Journal of Clinical Psychology, 10, $299-$ 304.

38. Jahoda, M. (1958). Current Concepts of Positive mental health. New York: Basic Books. 